\title{
Analisis Penyebab Tingginya Angka Hairiness pada Benang Cd 40's di Mesin Ring Spinning Perusahaan Pembuatan Benang PT XYZ
}

\author{
Mokh Afifuddin*1, Sugiyarto ${ }^{2}$, dan Isna Rusdiana ${ }^{3}$ \\ 1,2,3 Akademi Komunitas Industri Tekstil dan Produk Tekstil Surakarta, 57126, Indonesia \\ Email: afifuddin@ak-tekstilsolo.ac.id ${ }^{1}$, sugiyarto@ak-tekstilsolo.ac.id ${ }^{2}$, rusdiana@gmail.com ${ }^{3}$
}

\begin{abstract}
Abstrak
Industri tekstil merupakan salah satu komoditi andalan industi manufaktur sekaligus menjadi motor penggerak pembangunan ekonomi nasional. PT XYZ merupakan salah satu industri tekstil terbesar yang yang memproduksi benang. Pengendalian mutu harus dilakukan untuk mencapai sasaran atau target yang telah ditetapkan perusahaan. Dari beberapa kualitas yang harus diuji hairiness menjadi perhatian tersendiri, karena di PT XYZ terdeteksi adanya angka hairiness yang tinggi melebihi standar dan toleransi. Maka penelitian ini bertujuan untuk menganalisa penyebab utama atas tingginya hairiness dalam proses produksi benang CD 40's di mesin ring spinning, serta dilakukan upaya penyelesaian dari masalah tersebut. Metode menganalisa permasalahan dengan menggunakan pendekatan diagram fishbone untuk mencari akar masalah dari permasalahan yang dihadapi. Ditemukan penyebab tingginya hairiness (bulu benang) pada benang CD 40's karena snail wire yang cacat. Sehingga perlu dilakukan action plan untuk menangani masalah tersebut. Setelah dilakukan perbaikan, terjadi penurunan angka hairiness (bulu benang) sebesar $22 \%$ dan peningkatan strength (kekuatan) sebesar 10\%..
\end{abstract}

Kata kunci: Bulu Benang, Fishbone, Kualitas, Ring spinning, Snail wire

\begin{abstract}
The textile industry is one of the mainstay commodities in manufacturing as well as a driving force for national economic development. PT XYZ is one of the largest textile industries producing yarn. Quality control must be carried out to achieve the goals or targets that have been set in a company. From several qualities of hairiness it is a particular concern, because PT XYZ has detected a high rate of hairiness that exceeds standards and tolerances. So this study aims to analyze the main cause of the high hairiness in the CD 40's yarn production process in the ring spinning machine, and an effort is made to resolve the problem. The method of analyzing the problem uses a fishbone diagram approach to find the root cause of the problem at hand. The method of analyzing the problem uses a fishbone diagram approach to find the root cause of the problems faced. It was found that the cause of high hairiness on CD 40's thread was due to a defective snail wire. So it is necessary to do an action plan to deal with this problem. After the repairs were carried out, there was a decrease in the hairiness rate by $22 \%$ and an increase in the strength by $10 \%$..
\end{abstract}

Keywords: Fishbone, Hairiness, Quality, Ring spinning, Snail wire.

\section{Pendahuluan}

Industri tekstil merupakan salah satu komoditi andalan industi manufaktur sekaligus menjadi motor penggerak pembangunan ekonomi nasional. Industri tekstil saat ini ditantang untuk dapat terus meningkatkan daya saing dan mengoptimalkan eksistensinya di pasar internasional. Oleh sebab itu peningkatan daya saing merupakan kata kunci yang harus diperhatikan agar industri tekstil dapat meningkatkan eksistensinya baik di pasar dalam negeri maupun internasional. Afifuddin (2019) menyatakan bahwa persaingan pada suatu industri bukan hanya mengenai seberapa tinggi tingkat produksi dan seberapa rendahnya tingkat harga, tetapi dilihat dari kualitas suatu produk serta ketepatan waktu pencapaianya.

\footnotetext{
${ }^{*}$ Penulis korespondensi
}

PT XYZ merupakan salah satu industri tekstil terbesar yang memiliki segmen pasar nasional dan internasional yang memproduksi benang, kain dan produk tekstil atau garmen. PT XYZ memiliki 3 unit departemen yaitu pemintalan, pertenunan dan garmen. Pemintalan adalah salah satu bidang tekstil yang menghasilkan produk berupa benang. PT XYZ memiliki 3 unit khusus pemintalan dengan kapasitas 56.727 bale/tahun. Angka produksi tersebut terbilang tinggi, dan setiap tahunnya target tersebut selalu terpenuhi. Kebutuhan akan benang, baik memenuhi pesanan maupun untuk proses selanjutnya di departemen pertenunan mendorong para operator untuk dapat mengejar target produksi yang telah direncanakan. 
Proses utama pembuatan benang pada proses pemintalan salah satunya adalah pada mesin Ring Spinning. Mesin Ring Spinning berfungsi untuk mengubah gulungan roving menjadi benang dengan cara di twist dan diregangkan melalui part-part tertentu (Hananto, 2018). Pada mesin tersebut terdapat berbagai faktor penentu kualitas benang maupun efisiensi produksi. Kualitas pada benang diklasifikasikan sesuai dengan alat ujinya. Kualitas benang meliputi ketidakrataan benang (U\%), kekuatan benang (strength) dan mulur benang (Elongation), bulu benang (hairiness), Ne atau nomor benang, TPI ( Twist Per Inch) dan total IPI (Imperfection Indicator) yang meliputi Thin, Thick dan Nep (gumpalan serat yan tidak bisa diuraikan) (Carissoni, Dotti, Fleiss, Petccia, \& Pieri, 2002).

Pengendalian mutu adalah kegiatan yang harus dilakukan untuk mencapai sasaran atau target yang telah ditetapkan pada suatu perusahaan. Dalam hal ini, pengendalian mutu difokuskan pada kualitas hasil produksi (Lusiana, 2007). Hasil produksi di pemintalan adalah benang, untuk itu kualitas yang harus diperhatikan adalah nomor benang (Ne), kerataan benang (U\%), TPI atau antihan, kekuatan/mulur benang dan total IPI meliputi Thin (tipis), Thick (tebal) dan Nep (gumpalan serat yang tidak bisa diuraikan). Untuk melakukan pengendalian tersebut ada beberapa hal yang harus dipertimbangkan seperti bahan baku, tenaga kerja, mesin yang digunakan dan proses produksi (Wijayono, Iskandar, Rohmah, Irwan, \& Putra, 2017).

Dari beberapa kualitas yang telah disebutkan di atas, permasalahan pada hairiness menjadi perhatian tersendiri. Karena dari hasil pengujian harian mesin Ring Spinning di PT XYZ terdeteksi adanya angka hairiness yang tinggi melebihi standar dan toleransi. Hairiness atau bulu benang adalah serat-serat yang menonjol pada permukaan benang sepanjang > $1 \mathrm{~mm}$ (Majumdar, 2010). Tingginya hairiness pada benang Ring Spinning dapat menyebabkan kekuatan dari benang itu sendiri rendah dan dapat pula berdampak pada proses berikutnya, yaitu kain akan terlihat kusut (Pawitro, 1975).

Penelitian terkait tentang penyebab munculnya hairiness terhitung sangat langka. Namun ada beberapa penelitian yang terkait dalam menganalisa kualitas produk benang di mesin ring spinning, diantaranya Fitriyani \& Herliansyah (2015) melakukan penelitian terkait kualitas benang CD-32 terhadap pengaruh kehandalan mesin ring spinning. Hermanto (2016) melakukan penelitian terkait kualitas benang pada mesin ring spinning sebelum dan sesudah overhoul. Wijaya dan Sulistyadi (2020) menganalisa terkait mutu benang terkait imperfection indicator dengan memberikan variasi diameter flange ring dan nomor traveler pada mesin ring spinning.

Adapun penelitian ini menganalisa kualitas benang pada proses produksi di mesin ring spinning PT XYZ yang terdeteksi banyaknya angka hairiness (bulu benang) yang melebihi dari nilai standar yang ditentukan oleh perusahaan. Angka hairiness yang tingg akan membuat strength (kekuatan) benang menjadi rendah. Sehingga dari latar belakang di atas didapatkan identifikasi masalah yang dirumuskan dalam research question yaitu: apa penyebab utama dari tingginya angka hairiness pada uji mutu benang CD'40's di mesin ring spinning?. Rumusan masalah dibuat untuk menetukan arah pada penelitian ini. Adapun tujuan dari penelitian ini adalah untuk menganalisa penyebab utama atas tingginya hairiness dalam proses produksi benang CD 40's di mesin ring spinning, serta dilakukan upaya penyelesaian dari masalah tersebut. Sehingga dapat meningkatkan mutu dari produksi di PT XYZ.

\section{Metode Penelitian}

Penelitian ini menggunakan studi kasus untuk mendapatkan pemahaman mengenai suatu permasalahan. Penelitian ini dilakukan pada Departemen Spinning 2 PT XYZ selama 3 bulan dari bulan Juni-Agustus. Metode yang digunakan adalah metode deskriptif. Metode deskriptif dipergunakan untuk menghimpun kondisi yang ada di lapangan. Pengumpulan data dilakukan dengan cara observasi dan wawancara secara langsung. Setelah data dikumpulkan berdasarkan pengamatan, selanjutnya dilakukan pengujian kualitas benang di laboratorium untuk memastikan kondisi awal terhadap permasalahan yang terjadi. Tahap berikutnya menganalisa permasalahan dengan menggunakan pendekatan diagram fishbone untuk mencari akar masalah dari permasalahan yang dihadapi. Setelah dilakukan analisa dan diketahui penyebab utama dari permasalahan maka dilakukan percobaan dengan memperbaiki bagian yang menjadi faktor penyebab utama. Setelah itu akan dilakukan pengujian kualitas kembali di laboratorium menggunakan Uster Tester dan MesdanLab Strenght Tester untuk memastikan kualitas kekuatan benang CD 40’s..

\section{Hasil dan Pembahasan}

Pengamatan dilakukan pada mesin Ring Spinning Merek Toyoda 1982 tipe RY No.B9 dengan jumlah spindel 480 kecepatan mesin $15000 \mathrm{rpm}$ yang memproduksi jenis benang dengan Ne CD 40's. Hasil pengujian awal benang CD 40's menggunakan alat Uster Tester dapat dilihat pada tebel berikut:

Tabel 1. Data Hasil Pengujian Kualitas Benang CD 40's

\begin{tabular}{llll}
\hline Item Uji & $\begin{array}{l}\text { Standar } \\
\text { Kualitas }\end{array}$ & Toleransi & $\begin{array}{l}\text { Hasil } \\
\text { Pengujian }\end{array}$ \\
\hline $\begin{array}{l}\text { U\% } \\
\text { Thin places } \\
(<50 \%)\end{array}$ & $\begin{array}{l}10.72 \\
\begin{array}{l}\text { Thick places } \\
(>50 \%)\end{array}\end{array}$ & $\begin{array}{l}\text { Max 12.90 } \\
\text { Max 29.00 }\end{array}$ & $\begin{array}{l}12.35 \\
23\end{array}$ \\
$\begin{array}{l}\text { Nep (>200\%) } \\
\text { Hairiness }\end{array}$ & 211.00 & Max 243 & 238 \\
\hline
\end{tabular}


Hasil uji benang CD 40's pada mesin Ring Spinning Toyoda menggunakan alat Uster Tester menunjukkan angka hairiness tinggi dan melebihi standar. PT XYZ memberikan acuan standar hairiness untuk proses $C D$ 40's adalah 3.80 dengan toleransi max 5.90, namun hasil uji yang telah dilakukan pada benang CD 40's dari mesin Ring Spinning Toyoda tipe RY No. B9 menunjuk pada angka 6.35. Hal ini tentu dapat berdampak pada proses berikutnya. Sehingga harus dilakukan analisis mengenai penyebab munculnya hairiness khususnya di bagian teknik atau mesin. Maka tahap selanjutnya dilakukan analisa menggunakan diagram fishbone untuk mengidentifikasi penyebab-penyebab dari permasalahan yang didapat. Berikut diagram fishbone dengan pendekatan 4 M's terkait permasalahan tingginya hairiness:

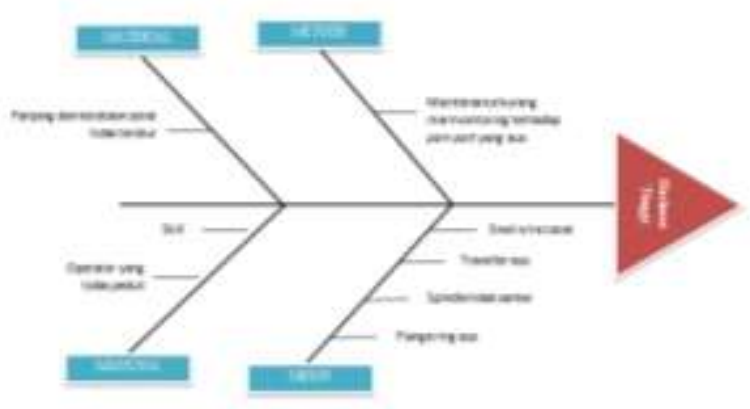

Gambar 1. Diagram fishbone Tingginya Hairness

Dari analisa tersebut, dilakukan pengamatan secara langsung terkait sumber-sumber yang dianggap penyebab utama yang paling dominan. Berikut uraian megenai faktor yang mempengaruhi hairiness sebagai berikut:.

1. Material, dilihat dari segi material yang harus dipastikan adalah panjang dan kerataan serat kapas yang digunakan untuk proses CD 40's. Menurut pengamatan dan hasil wawancara serat kapas yang menjadi bahan baku sudah sesuai dengan standar dengan panjang serat yang sudah ditetapkan yaitu 1 1/8. Maka dapat disimpulkan bahwa material tidak menjadi penyebab dari hairiness yang terjadi di mesin ring spinning.

2. Manusia, pertama skill yang dimaksud disini adalah kecepatan operator dalam menyambung benang, sebab semakin lama gulungan benang berputar tanpa benang tersambung dapat memicu timbulnya hairiness. Berdasarkan pengamatan dan dilakukan tes sambung benang kepada operator secara sampling didaptkan operator mampu menyelesaikan 14 sambungan dalam waktu 1 menit. Kedua adalah kepedulian, kurngnya kepudulian opertaor membiarkan travller cleaner kotor dan memasang travller bekas mengakibatkan timbulnya hairness. Dari hasil pengamatan tidak ditemukan hal tersebut, sehingga dapat disimpulkan bahwa faktor manusia tidak menjadi penyebab utama hairiness.

3. Metode, monitoring mesin adalah salah satu kegiatan pemantauan kondisi mesin secara visual yang berhubungan dengan operasional produksi sehingga dapat diambil suatu tindakan (Haryono \& Susanty, 2018). Maintenance unit spinning 2 PT XYZ sudah melaksanakan JPM (jadwal preventive maintenance) seperti scouring, cleaning, penggantian suku cadang sesuai dengan life time, pemberian oli, grease dan sebagainya. Maka dapat disimpulkan faktor ini masih bukan menjadi penyebab utam hairiness yang terjadi di PT XYZ saat pengamatan ini dilakukan.

4. Lingkungan, lingkungan pada pembahasan ini adalah lokasi kerja maupun area sekitar mesin. Biasanya area yang kotor bias menyebabkan Fly waste karena kotoran yang tertiup oleh blower dan dapat menyebabkan hairiness. Namun saat pengamatan dilakukan dan berdsarkan wawancara pembersihan rutin dilakukan. Kondisi temperatur yang panas di ruangan mesin Ring Spinning juga dapat memicu elektrostatis yang tinggi antara benang dan sparator, sehingga menimbulkan hairiness. Berdasarkan Thermo Hygro (alat pendeteksi RH dan Temperatur) yang terpasang di area mesin Ring Spinning, temperatur di area mesin Ring Spinning sudah sesuai dengan standar yang ditetapkan yaitu RH $50-59 \%$ dan temperatur $28-34 \mathrm{o}$ C.

5. Mesin, Salah satu faktor yang paling memicu timbulnya hairiness dari segi mesin adalah karena keausan part mesin Ring Spinning seperti traveller aus, flange ring aus, spindle tidak senter dan snail wire cacat (Hangzhou, 2019). Untuk mengetahui penyebab paling dominan timbulnya hairiness (bulu benang) dari faktor mesin, penulis melakukan pengamatan dan wawancara keabagian mekanik. Berdasarkan informasi dari bagian mekanik yang dianggap mengetahui tentang masalah yang disebabkan oleh mesin, diperoleh pernyataan dan data bahwa semua part sudah dilakukan penggantian dan saat ini dalam kondisi bagus kecuali snail wire. Sehingga, dianggap penyebab tingginya hairiness (bulu benang) pada benang CD 40's karena snail wire yang cacat. Maka dari itu perlu adanya pembuktian. Penulis melakukan pengamatan langsung di mesin dan terbukti banyak ditemukan snail wire cacat dengan indikasi benang yang keluar dari draft zone 
melalui snail wire yang akan digulung ke cop hanya mnggearis satu alur, tidak membuat alur kekanan dan kekiri seperti yang terlihat pada gambar di bawah ini.

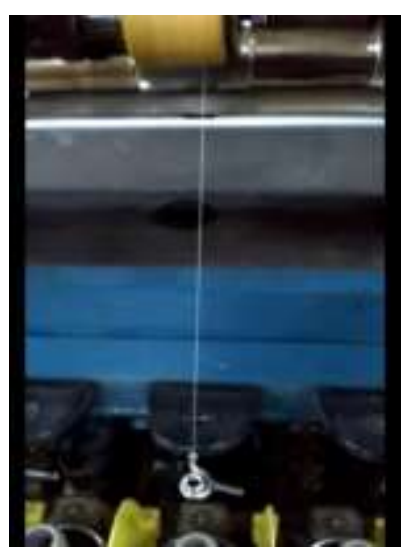

Gambar 2. Snail Wire pada Mesin Ring Spinning

Sail wire adalah salah satu part yang berfungsi meghantarkan benang yang keluar dari draft zone dan kemudian digulung pada cop, maka dari itu snail wire harus memiliki sifat tahan terhadap gesekan, akan tetapi semakin lama penggunaan snail wire maka dapat mengakibatkan pengikisan pada permukaan snail wire (Wang, Xin, Deng, Li, \& Liu, 2018). Dari permasalahan tersebut maka perlu dilakukan action plan untuk menangani masalah diatas, berikut action plan dengan prinsip $5 \mathrm{~W}+1 \mathrm{H}$.

Tabel 2. Data Hasil Pengujian Kualitas Benang CD 40's

\begin{tabular}{ll}
\hline $5 \mathrm{~W}+1 \mathrm{H}$ & Uraian \\
\hline What & Kondisi snail wire cacat \\
Who & Penulis dan Leader Maintenance Ring \\
& Spinning \\
Where & Mesin Ring Spinning Toyoda tipe RY Tahun \\
& 1982 No. B9, unit Spinning 2 PT XYZ \\
When & 16 Agustus 2019 \\
How & Penggantian dan sentering snail wire cacat \\
How Much & 90 buah dari 480 spindle \\
\hline
\end{tabular}

Setelah action plan diatas dilaksanakan maka perlu dilakukan pengamatan mesin dan pengujian benang kembali menggunakan alat uji uster tester untuk memastikan sudah tidak ada lagi snail wire cacat dan memastikan tidak ada angka hairiness yang tinggi melebihi standar kualitas yang telah ditentukan, berikut perbandingan data pengujian benang setelah dan sebelum penggantian snail wire.

Tabel 3. Perbandingan Hasil Pengujian Sebelum dan Sesudah Perbaikan Snail Wire

\begin{tabular}{lll}
\hline Item Uji & $\begin{array}{l}\text { Hasil Pengujian } \\
\text { Sebelum }\end{array}$ & $\begin{array}{l}\text { Hasil Pengujian } \\
\text { Setelah }\end{array}$ \\
& Perbaikan & Perbaikan \\
\hline U\% & 12.35 & 12.62 \\
Thin places & 23 & 18 \\
$(<50 \%)$ & &
\end{tabular}

\begin{tabular}{lll}
$\begin{array}{l}\text { Thick places } \\
(>50 \%)\end{array}$ & 238 & 248 \\
Nep $(>200 \%)$ & 429 & 317 \\
Hairiness & 6.35 & 4.96 \\
\hline
\end{tabular}

Dari data perbandingan pengujian benang setelah dan sebelum penggantian snail wire di atas, dapat diketahui bawa terjadi penurunan angka hairiness (bulu benang) $22 \%$ dari 6.35 menjadi 4.96, hal ini masih sesuai dengan batas kualitas yang ditetapkan yakni 4.50-5.90. Sedangkan pada pengujian strength yang dilakukan dengan menggunakan alat uji MesdanLab Strenght Tester juga mengalami peningkatan 10\% dari 194.155 sebelum perbaikan menjadi 216.558 setelah perbaikan. Sehingga kekuatan benang jenis Cd 40's pada mesin ring spinning Toyoda RY B9 sudah memenuhi standar kualitas yang ditetapkan perusahaan. Dapat disimpulkan bahwa penggantian snail wire cacat dapat menjaga kualitas benang Cd 40's dan dapat menurunkan angka hairiness serta meningkatkan strength yang cukup signifikan.

\section{Kesimpulan}

Berdasarkan hasil analisa data di atas dapat disimpulkan bahwa faktor yang menyebabkan tingginya angka hairiness (bulu benang) dan rendahnya strength (kekuatan) benang CD 40's pada mesin Ring Spinning Toyoda tipe RY No. B9 berdasarkan alat Uster Tester 3 dan MesdanLab Strenght Tester adalah karena snail wire yang cacat. Sehingga harus dilakukan penanganan dengan cara penggantian dan sentering snail wire. Setelah dilakukan penggantian dan sentering snail wire terjadi penurunan angka hairiness (bulu benang) sebesar $22 \%$ dan peningkatan strength (kekuatan) sebesar 10\% setelah penggantian. Untuk mengantisipasi terjadinya snail wire cacat perlu dilakukan pelatihan kepada bagian maintenance tentang indikator snail wire cacat dan beberapa part yang mempengaruhi terhadap kualitas benang. Dirutinkan scouring dan dicatat ke dalam buku monitoring perbaikan mesin untuk evaluasi. Perlu juga dilakukan usulan metode perencanaan perawatan mesin di PT XYZ pada penulisan selanjutnya. Diharapkan saran tersebut dapat membantu perbaikan kualitas haireness dan streght benang, sehingga kualitas benang dapat dipertahankan sesuai standar serta dapat memenuhi keinginan customer sesuai dengan spesifikasi yang telah ditentukan..

\section{Daftar Pustaka}

Afifuddin, M. (2019). Penerapan Line Balancing Menggunakan Metode Ranked Position Weight (RPW) untuk Meningkatkan Output Produksi pada Home Industri Pembuatan Sepatu Bola. Journal of Industrial Engineering, 39-46. 
Carissoni, E., Dotti, S., Fleiss, F., Petccia, L., \& Pieri, L. (2002). Spiining Cotton and Wool Spinning. Reference Books of Textile Technologies.

Fitriyani, I. W., \& Herliansyah, M. K. (2015). Pengaruh Kehandalan Mesin Ring Spinning Terhadap Kualitas Produk Benang CD-32. etd repository ugm.

Hananto, A. (2018, Desember). Perancangan dan Pembuatan Sistem Transmisi Regangan (Drafting) dan Antihan (Twisting) pada Mesin Ring Spining Berbasis Mikrokontroller. Metal Indonesia, 40, 7486.

Hangzhou. (2019, September 27). Hangzhou Yiniu Chemical Fiber. Dipetik Desember 2020, dari http://id.yiniuacy.com/:

http://id.yiniuacy.com/news/basic-knowledge-ofyarn-hairiness-28299645.html

Haryono, L., \& Susanty, A. (2018). Penerapan Total Productive Maintenance dengan Pendekatan Overall Equipment Effectiveness (OEE) dan Penentuan Kebijakan Maintenance pada Mesin Ring Frame Divisi Spinning I DI PT Pisma Putra Textile. Indusrial Engineering Online Journal, 3.

Hermanto. (2016). Perbandingan Kualitas Benang Ne 40 s Carded pada Mesin Ring Spinning Sebelum dan Sesudah Overhaul. Faktor Exacta, 5(3), 210-216.

Lusiana, A. (2007). Analisis Pengendalian Kualitas Produk Dengan Menggunakan Metode Six Sigma Pada PT. Sandang Nusantara Unit Patal Secang. Semarang: Thesis Fakultas Ekonomi.

Majumdar, A. (2010). Yarn hairiness and its reduction (Technical Textile Yarns ed.). (A. D. R. Alagirusamy, Penyunt.) Woodhead Publishing.

Pawitro. (1975). Teknologi Pemintalan. Bandung: Institut Teknologi Bandung.

Wang, W., Xin, B., Deng, N., Li, J., \& Liu, N. (2018). Single Vision Based Identification of Yarn Hairiness Using Adaptive Hreshold and Image Enhancement Method. Measurement, 128, 220230.

Wijaya, T. B., \& Sulistyadi. (2020). Peningkatan Kualitas Imperfection Indicator (IPI) Benang P/C Ne1 45 pada Mesin Ring Spinning Toyoda Model RY dengan Setting Variasi Diameter Ring Flange dan Nomor Traveller. Jurnal Teknika, 95-102.

Wijayono, A., Iskandar, S., Rohmah, S., Irwan, \& Putra, V. G. (2017). Penerapan Teknologi Pengolah Citra dan Fisika pada Bidang Tekstil. Yogyakarta: CV Mulia Jaya. 